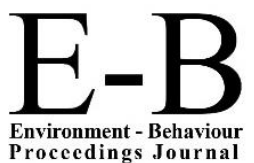

Environment - Behaviour

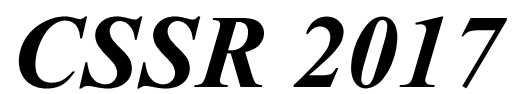

https://www.amerabra.org; https://fspu.uitm.edu.my/cebs; https://www.emasemasresources.com

$4^{\text {th }}$ International Conference on Science \& Social Research

The Pines, Malacca, Malaysia, 06 -07 December 2017

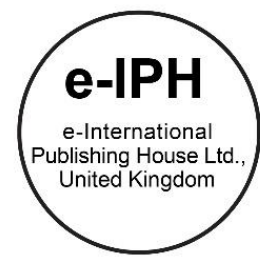

\title{
Report-writing Disposition and Achievement Orientation: An exploratory research on MUET students
}

\author{
Boo Ho Voon', Ai Kiat Teo², Joyce E.C. Voon ${ }^{3}$ \\ ${ }^{1}$ Faculty of Business and Management, Universiti Teknologi MARA, Malaysia. ${ }^{2}$ SMK DPHA Gapor, Kuching, Malaysia. \\ ${ }^{3}$ Institut Pendidikan Guru, Bahasa Antarabangsa, Kuala Lumpur, Malaysia \\ bhvoon@uitm.edu.my, aikita67@yahoo.com,voonerncze@gmail.com \\ Tel of 1st Author: +6019-4390228
}

\begin{abstract}
This paper aimed to gauge the MUET students' report-writing dispositions and achievement orientation as well as examine the influence of selected demographic variables on these two variables. The research was conducted on two groups of MUET students (79 students) in a government secondary school in Kuching. The findings indicated that the multi-item writing disposition and achievement orientation were reliable. These two variables were having a weak association. The report-writing dispositions of the surveyed MUET students were generally low, but their achievement orientations were satisfactory. The demographic variables had significant influences on their report-writing disposition, but not their achievement orientations.
\end{abstract}

Keywords: Report-writing disposition; Achievement orientation; MUET English

eISSN: 2398-4287 @ 2020. The Authors. Published for AMER ABRA cE-Bs by e-International Publishing House, Ltd., UK. This is an open access article under the CC BYNC-ND license (http://creativecommons. org/licenses/by-nc-nd/4.0). Peer-review under responsibility of AMER (Association of Malaysian Environment-Behaviour Researchers), ABRA (Association of Behavioural Researchers on Asians) and cE-Bs (Centre for Environment-Behaviour Studies), Faculty of Architecture, Planning \& Surveying, Universiti Teknologi MARA, Malaysia.

DOI: https://doi.org/10.21834/ebpj.v5iSI1.2316

\subsection{Introduction}

The Malaysian Education Department is always keen and active in improving the standard of English among secondary school students. There is a continuous and consistent process of training the teachers (e.g. Benson and Enström, 2017) as well as the administrators. The Malaysian government has been emphasizing the importance of English and the competence of English teachers. Nevertheless, there are still rooms for improvement in terms of students' command of English. One of the challenges faced by the MUET students is on writing, typically the report-writing. Their scores on Paper 4 (Report) were found to be relatively lower. They should be able to write a good report that can meet the expectations. The findings (Teo, 2010) suggested that the Expectation-based Teaching (EBT) approach of teaching had significantly improved the writing performance of the MUET students.

Though the teaching approach can be practical, the attitude of the students will also play an essential role in learning. The attitude towards English report-writing will most probably facilitate the teaching and learning processes. The results in the previous study also hinted that those who liked English reports tend to have relatively higher scores in their Report-writing tests. Besides, their achievement orientation may exert some influence too. Besides, the possible demographic influences on these two antecedents to learning performance should be investigated to achieve more holistic, effective management of the English-report writing teaching process. The main objective of this survey research is to explore the report-writing dispositions and achievement orientation of the MUET students, as well as investigate the demographic influences on these variables. The specific objectives are: i) To explore the report-writing disposition of the MUET students, ii) To explore the achievement orientation of the MUET students, iii) To examine the associations of report-writing disposition and achievement orientation of students on their report-writing performance, and iv) To examine the influences of demographic variables on the report-writing disposition and achievement orientation of the sampled MUET students. 


\subsection{Related Literature and Research Model}

The management scholars and practitioners suggest that the high performing organizations and individuals are very competent in terms of serving their target customers. They are very customer-oriented. It is also observed that more and more researchers have illuminated marketing mechanisms in the education sector (e.g. Edwards and Kuhlman, 2007; Green, 2006; Mehra and Rhee, 2009; Voon, 2006). Besides, market orientated attitudes and behaviours in teaching are recommendable for better customer benefits. Customer satisfaction (or student satisfaction) also need to be taken into consideration (e.g. Ihtiyar, 2018; Jaggar, Folk \& Mullins, 2018; Latino, Latino \& Latino, 2019). Kohli and Jaworski (1990) emphasized the generation, dissemination and responsiveness to the relevant information. This market-oriented culture can help to create superior customer value (Narver and Slater, 1990). The teachers need to be student-oriented and adopt interactive approach in teaching (e.g. Suarmi \& Fatimah, 2019). In fact, a lot of empirical research suggested that understanding the students' needs and then teachers will be more effective (e.g. Edwards and Kuhlman, 2007). Figure 1 shows the research model for this exploratory research. The independent variables are report-writing dispositions (RWD) and achievement orientation (AO) of the MUET students, whereas the dependent variable is the report-writing performance (RWP). The influences of demographic variables were analyzed accordingly.

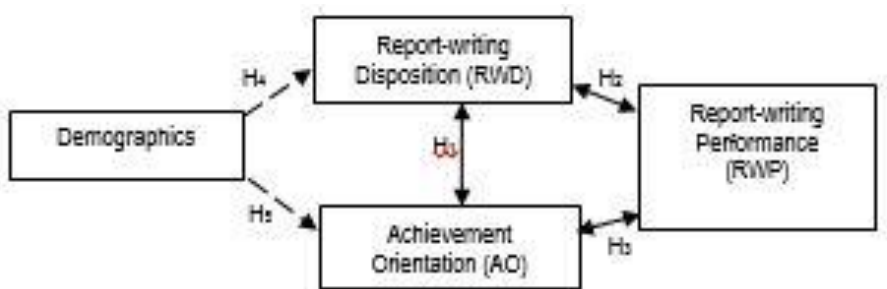

Figure 1: The Research Model

Specifically, the five significant hypotheses which were tested in this exploratory research were:

$\mathrm{H}_{1}$ : $\quad$ Report-writing Dispositions and Achievement Orientation are associated.

$\mathrm{H}_{2}$ : $\quad$ Report-writing Dispositions is positively associated with Report-writing Performance

$\mathrm{H}_{3}: \quad$ Achievement Orientation is positively associated with Report-writing Performance

$\mathrm{H}_{4}$ : Demographic variables have significant influences on Report-writing Dispositions

$\mathrm{H}_{5}$ : Demographic variables have significant influences on Achievement Orientation

\subsection{Methodology}

This exploratory research aimed to gauge the report-writing dispositions and achievement orientation of the participating MUET students. The data were collected at a government secondary school in Kuching. Structured questionnaires were used to collect the self-reported data, and the sample size was seventy-nine ( $n=79)$.

The research instrument was made up of two main sections, namely Section A: Demographic Variables and Section B: Reportwriting dispositions and achievement orientation. The demographic information included: gender, race, English speaking norms, parents' income, father's occupation, and SPM grade. Report-writing disposition was measured by adapting the multi-item scale of Piazza and Siebert (2008), whereas the achievement orientation measure has adapted the scale which was developed by Cumming et al. (2008). The duly pre-tested questionnaires were distributed to the sampled classes of MUET students in the school. Each respondent used about 10 minutes to answer the questionnaire carefully. The duly answered and returned questionnaires were checked and coded accordingly before the data entry process.

The quantitative data analysis phase involved reliability checks (internal consistency using Cronbach's Alpha coefficients and itemto-total correlations), Pearson correlations, Mean differences analyses using t-test and ANOVA (F-test). The demographic influences were investigated using the comparisons of means between or among the independent sample groups. For instance, the means between male and female groups, the means among the different racial groups, and so forth.

\subsection{Results}

The results in Table 1 show the reliability and descriptive statistics of the variables. The statistical results of the reliability analysis indicated that the two multi-item measures (i.e., report-writing dispositions and achievement orientation) possessed a satisfactory level of reliability. The Cronbach's alpha coefficients of the former stood at 0.88 , whereas the latter was 0.87 , both were higher than the mandatory level of 0.70 (Nunnally and Bernstein, 1994; Churchill, 1979). Besides, the item-to-total correlations of all the items of the respective measures had also surpassed the required level of 0.40 (e.g. Nunnally and Bernstein, 1994; Voon, Douglas and Baljinder, 2012; Voon, Firdaus, Lee and Kueh, 2014; Voon, Jamil, Patricia, Teo and Agnes, 2017). As such, these constructs most probably were able to measure the intended information reliably. The Report-writing Dispositions (RWD) consisted of ten items, whereas Achievement Orientation (AO) also contained 10 items. 
Measuring the scale continuum of 1 to 7 , the average score for RWD of the sampled 79 students was only 3.21 , which was below mid-point of 4 (7-point scale). This indicated that the students were rather incompetent and uninterested in English report-writing. The items with relatively low score were:

- I enjoy writing reports in English (2.95)

- I always look forward to report-writing (2.72)

- I can write good reports in English (2.57)

- Writing report in English is easy for me (2.37)

- My report-writing skill is among the best in class (2.11)

Nevertheless, they did admit that Report-writing was important (mean score of 4.91). Besides, they were willing to try and learn to improve their report-writing skills and performance. These could be seen from the mean scores of 3.92 for 'I take time to solve problems in report-writing' and 3.87 for 'I will not mind writing more reports to learn'.

Table 1: Reliability Analysis with the Relevant Descriptive Statistics

\begin{tabular}{|c|c|c|c|c|}
\hline Variables & $\begin{array}{l}\text { Alpha } \\
\text { Value }\end{array}$ & $\begin{array}{l}\text { Item-total- } \\
\text { correlations }\end{array}$ & Mean & $\begin{array}{l}\text { Standard } \\
\text { Deviation }\end{array}$ \\
\hline $\begin{array}{l}\text { Report-writing Disposition Scale (1-7) } \\
\text { 1. Report-writing skill is among the best in class. } \\
\text { 2. I can write good reports in English. } \\
\text { 3. Writing report in English is easy for me. } \\
\text { 4. I enjoy writing reports in English. } \\
\text { 5. I always look forward to report-writing. } \\
\text { 6. I will try different ways/methods in the writing. } \\
\text { 7. I am willing to spend time on writing reports. } \\
\text { 8. I take time to solve problems in report-writing. } \\
\text { 9. I do not mind writing more reports to learn. } \\
\text { 10. Report-writing is an important skill. }\end{array}$ & 0.88 & $\begin{array}{ll}0.485 & 0.620 \\
0.621 & 0.542 \\
0.611 & 0.653 \\
0.770 & 0.536 \\
0.681 & 0.591\end{array}$ & $\begin{array}{l}2.11 \\
2.57 \\
2.37 \\
2.95 \\
2.72 \\
3.42 \\
3.29 \\
3.92 \\
3.87 \\
4.91\end{array}$ & $\begin{array}{l}1.1211 .070 \\
1.1231 .186 \\
1.0611 .383 \\
1.4161 .583 \\
1.6201 .478\end{array}$ \\
\hline $\begin{array}{l}\text { Achievement Orientation (Scale 1-5) } \\
\text { 1. My goal is to learn and be very good in English. } \\
\text { 2. The important thing is to be the best MUET } \\
\text { student } \\
\text { 3. The important thing is to improve my reporting } \\
\text { skills. } \\
\text { 4. My goal is to improve and be better than other } \\
\text { 5. I work hard to become the best in report-writing. } \\
\text { 6. I want to be better than others in report-writing. } \\
\text { 7. I feel successful when I learn a new skill. } \\
\text { 8. Success means being better than others. } \\
\text { 9. I feel successful when I do my best. } \\
\text { 10. My goal is to be better than others in report- } \\
\text { writing. }\end{array}$ & 0.87 & 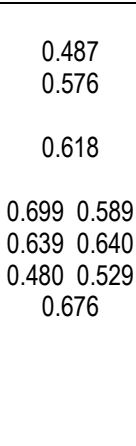 & $\begin{array}{l}3.73 \\
\\
3.30 \\
3.57 \\
3.35 \\
3.78 \\
3.04 \\
3.96 \\
3.15\end{array}$ & $\begin{array}{c}0.980 \\
1.010 \\
\\
0.943 \\
\\
1.054 \\
0.929 \\
0.9200 .996 \\
1.1491 .137 \\
1.063\end{array}$ \\
\hline
\end{tabular}

The level of achievement orientation for the MUET students was recommendable (i.e., 3.53, on the 5-point scale).

- My goal is to learn new skills and get as good as possible (3.96)

- I feel successful when I do my best (3.96)

- I feel successful when I learn a new skill (3.78)

- The most important thing is to improve my reporting skills (3.73)

The results from Pearson correlation analysis show that there is a significant association between Report-writing Dispositions and Achievement Orientation. These could be viewed at the level of significance of $1 \%(\alpha=0.01)$, the correlation coefficient $(r)$ which stood at 0.389 and the strength of correlation that is considered rather weak (Burns and Bush, 2000). Hence, hypothesis $\mathrm{H}_{1}$ was supported.

The correlations between Report-writing Dispositions (RWD) and Report-writing Performance (RWP) were reported at 0.141, which was insignificant. The same went to Achievement Orientation (AO) and Report-writing Performance (RWP), where the correlation coefficient was only 0.043 . Thus, Hypotheses $\mathrm{H}_{2}$ and $\mathrm{H}_{3}$ were not supported. The statistical results for the mean difference analyses are shown in Table 2. Generally, it was found that the demographic variables exerted significant influences on the report-writing dispositions, except for gender.

Table 2: Demographic Influences on Report-writing Disposition

\begin{tabular}{|l|c|c|c|c|c|}
\hline \multicolumn{1}{|c|}{ Variables } & $\begin{array}{c}\text { Sample } \\
\text { Sizes } \\
(\mathrm{n}=79)\end{array}$ & RWD Mean & $\mathrm{t} / \mathrm{F}$ & Sig. & Remarks \\
\hline Gender & 27 & 3.38 & 1.152 & 0.253 & $\begin{array}{c}\text { Not } \\
\text { Male } \\
\text { Female }\end{array}$ \\
\hline Race & 52 & 3.13 & & & \\
$\quad$ Malay & 14 & 2.95 & 5.127 & $0.008^{*}$ & Significant \\
$\quad$ Chinese & 36 & 3.56 & & & \\
\hline
\end{tabular}




\begin{tabular}{|c|c|c|c|c|c|}
\hline Dayaks & 29 & 2.92 & & & \\
\hline $\begin{array}{l}\text { English Speaking } \\
\text { Yes } \\
\text { No }\end{array}$ & $\begin{array}{c}7 \\
72\end{array}$ & $\begin{array}{l}3.47 \\
3.19\end{array}$ & 3.163 & $0.079^{\star *}$ & Significant \\
\hline $\begin{array}{l}\text { Parent's Income } \\
2000 \text { or less } \\
>2000\end{array}$ & $\begin{array}{l}57 \\
22\end{array}$ & $\begin{array}{l}3.03 \\
3.69\end{array}$ & 3.000 & $0.004^{*}$ & Significant \\
\hline $\begin{array}{l}\text { Father's Occupation } \\
\text { Public } \\
\text { Private } \\
\text { Self-employed } \\
\text { Unemployed }\end{array}$ & $\begin{array}{l}22 \\
20 \\
27 \\
10\end{array}$ & $\begin{array}{l}3.35 \\
3.65 \\
2.97 \\
2.70 \\
\end{array}$ & 3.706 & $0.015^{*}$ & Significant \\
\hline $\begin{array}{l}\text { Like To Read English Report } \\
\text { Yes } \\
\text { No }\end{array}$ & $\begin{array}{l}27 \\
52\end{array}$ & $\begin{array}{l}3.64 \\
2.99\end{array}$ & 3.131 & $0.002^{*}$ & Significant \\
\hline SPM Grade & 79 & \multicolumn{3}{|c|}{ Correlation coefficient $(r=0.625)^{*}$} & Significant \\
\hline
\end{tabular}

There was no significant difference in RWD between the male and female students. However, there were significant differences in the means for the groups which were differentiated by race, English speaking norms, parents' income, father's occupation, and Like to read English report. RWDs of the following MUET students were relatively higher:

- $\quad$ Chinese students

- $\quad$ Those who normally speak in English

- $\quad$ Parents' income more than RM2000 per month

- $\quad$ Father working in the private sector

- $\quad$ Those who like to read English reports.

Besides, the SPM grade had a moderate correlation with their report-writing dispositions.

The results shown in Table 3 suggested that the demographic background of the MUET students generally had no significant influence on their achievement orientation, except for the Father's Occupation. The students whose fathers were working in the public sector and self-employed tend to have higher AOs.

Table 3: Demographic Influences on Achievement Orientation

\begin{tabular}{|c|c|c|c|c|c|}
\hline Variables & $\begin{array}{l}\text { Sample } \\
\text { Sizes } \\
(n=79)\end{array}$ & AO Mean & $t / F$ & Sig. & Remarks \\
\hline $\begin{array}{l}\text { Gender } \\
\text { Male } \\
\text { Female } \\
\end{array}$ & $\begin{array}{l}27 \\
52 \\
\end{array}$ & $\begin{array}{l}3.38 \\
3.18 \\
\end{array}$ & 1.135 & 0.260 & Not significant \\
\hline $\begin{array}{l}\text { Race } \\
\text { Malay } \\
\text { Chinese } \\
\text { Dayaks }\end{array}$ & $\begin{array}{l}14 \\
36 \\
29\end{array}$ & $\begin{array}{l}3.59 \\
3.64 \\
3.36 \\
\end{array}$ & 1.381 & 0.258 & Not Significant \\
\hline $\begin{array}{l}\text { English Speaking } \\
\text { Yes } \\
\text { No }\end{array}$ & $\begin{array}{c}7 \\
72\end{array}$ & $\begin{array}{l}3.74 \\
3.51\end{array}$ & 0.845 & 0.401 & Not Significant \\
\hline $\begin{array}{l}\text { Parent's Income } \\
2000 \text { or less } \\
>2000\end{array}$ & $\begin{array}{l}57 \\
22\end{array}$ & $\begin{array}{l}3.49 \\
3.62\end{array}$ & 0.731 & 0.467 & Not Significant \\
\hline $\begin{array}{l}\text { Father's Occupation } \\
\text { Public } \\
\text { Private } \\
\text { Self-employed } \\
\text { Unemployed }\end{array}$ & $\begin{array}{l}22 \\
20 \\
27 \\
10\end{array}$ & $\begin{array}{c}3.69 \\
3.48 \\
3.643 .00\end{array}$ & 2.760 & $0.048^{*}$ & Significant \\
\hline $\begin{array}{l}\text { Like To Read English } \\
\text { Report } \\
\text { Yes } \\
\text { No }\end{array}$ & $\begin{array}{l}27 \\
52\end{array}$ & $\begin{array}{l}3.57 \\
3.51\end{array}$ & 0.366 & 0.751 & Not Significant \\
\hline SPM Grade & 79 & \multicolumn{3}{|c|}{$\begin{array}{l}\text { Correlation coefficient }(r=0.147, \\
\text { sig. }=0.195)\end{array}$} & Not significant \\
\hline
\end{tabular}

\subsection{Conclusion}

This exploratory research on the MUET students aimed to gauge their report-writing dispositions and achievement orientation as well as examined the influences of selected demographic variables. The entire research and intervention were conducted within ten weeks duration, and four groups of MUET students in a government secondary school in Kuching were involved. 
The findings indicated that the writing disposition scale of Piazza and Siebert (2008) and achievement orientation scale of Cumming et al. (2008) were reliable measures. They could be potentially adapted to measure the report-writing dispositions and achievement orientations of the MUET students. The correlation analysis indicated that the report-writing dispositions and achievement orientations were having a significant but rather weak association $(r=0.389)$.

Results from the descriptive statistical analyses suggested that report-writing dispositions of the surveyed MUET students were generally low (3.21 out of the 7-point scale), but their achievement orientations were recommendable (3.53 out of 5-point scale). In addition, demographic variables (race, English speaking norms, parents' income, father's occupation, and SPM grade) had significant influences on the report-writing dispositions, but not gender. As for achievement orientation, demographics generally had no significant influence, except for the Father's Occupation.

This questionnaire survey if can be replicated to cover more representative sample size, it will provide more useful insights for the MUET English teachers, advisors, the school management and educational policymakers. The conclusive information will help them to develop the relevant segmentation strategies to benefit the different student groups more effectively. For instance, planning more effective strategies to improve the report-writing dispositions of the MUET students, whose fathers' occupations were self-employed or unemployed as their report-writing dispositions were found to be comparatively lower.

\section{Acknowledgments}

The authors would like to thank the participating students who rendered their kind co-operation along the entire process of the data collection. Thanks to the CSSR 2017 Chair and Organizing Teams. Besides, the financial support from UiTM Cawangan Sarawak is much appreciated.

\section{References}

Benson, L., \& Enström, R. (2017). Deliberate institutional differentiation through graduate attributes: Implementing professional skills at MacEwan School of Business. Journal of Management Development, 36 (6), 817-827.

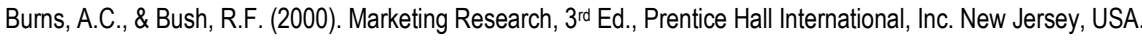

Churchill, G. (1979). A Paradigm for Developing Better Measures of Marketing Constructs, Journal of Marketing Research, Vol. XVI (February), 64-73.

Creese, A. (2005). Is this content-based language teaching? Linguistics and Education, 16, 188-204.

Cumming, S.P., Smith, R.E., Mall, F.L., Standage, M., \& Grossbard, J.R. (2008). Development and validation of the Achievement Goal Scale for Youth Sports. Psychology of Sport and Exercise, 9, 686-703.

Edwars, S.,\& Kuhlman, W. (2007). Culturally responsive teaching: Do we walk our talk? Multicultural Education, Summer, 45-49.

Forza, C. (2002). Survey research in operations management: A process-based perspective. International Journal of Operations \& Production Management, 22(2), 152194.

Garner, M.,\& Borg, E. (2005). An ecological perspective on content-based instruction. Journal of English for Academic Purposes, 4, 119-134.

Green, A. (2006). Wash back to the learner: Learner and teacher perspectives on IELTS preparation course expectations and outcomes. Assessing Writing, 11, 113-134.

Hendricks, C. (2006). Improving schools through action research: A comprehensive guide for educators. Boston, MA: Pearson Education, Inc.

Ho, Belinda (1997). Reactions of Students to Reflective Learning in a Technical Report-writing Course. English for Specific Purposes, 16(3), 211-227.

Intiyar, A. (2018). Interaction of intercultural service encounters: Personality, intercultural communication and customer satisfaction. Asia Pacific Journal of Marketing, 30 (1), 2-22.

Jaggar, S.S., Folk, A.L. \& Mullins, D. (2018). Understanding students' satisfaction with OERs as course materials. Performance Measurement and Metrics, 19 (1), 66-74.

Johnson, A.P. (2005). A short guide to action research, 2nd Ed. Boston, MA: Pearson Education, Inc.

Latino, M.A., Latino, R.J. \& Latino, K.C. (2019). Root Cause Analysis: Improving Performance for Bottom-Line Results, $5^{\text {th }}$ Ed., Boca Raton: CRC Press, Taylor \& Francis Group.

Mehra, S.,\& Rhee, M. (2009). On the application of quality management concepts in education: An example of a Korean classroom. International Journal of Quality \& Reliability Management, 26(4), 312-324.

Molhotra, N. (2009). Marketing research: An applied orientation. 6th Ed. Pearson Education, Inc.

Nunnally, J.C. \& Bernstein, I.H. (1994).Psychometric Theory, $3^{\text {rd }}$ ed., McGraww-Hill, Inc., New York.

Piazza, C.L. \& Siebert, C.F. (2008). Development and Validation of a Writing Dispositions Scale for Elementary and Middle School Students. The Journal of Educational Research, 101(5), 275-285. 
Suarmi, S.P. \& Fatimah, S. (2019). Implementing interactive writing to teaching writing to young learners. Journal of English Language Teaching, 8 (3), 357-364.

Teo, A.K. (2010).Improving the content quality of report-writing in MUET: An action research on expectation-based teaching, unpublished research report, SMK DPHA Gapor, Kuching, Sarawak, Malaysia.

Voon, B.H. (2006). Linking a Service-Driven Market Orientation to Service Quality. Managing Service Quality, 16 (6), 595-619.

Voon, B.H., Douglas, A. \& Baljinder, S. (2012). Serving the local community customers: Evidence from multi-cultural Malaysia. International Journal of Business and Society, 13(3), 293-308.

Voon, B.H., Firdaus, A., Lee, N., \& Kueh, K. (2014). Developing a HospiSE scale for hospital service excellence. Journal of Quality \& Reliability Management, 31 (3), 261 280

Voon, B.H., Jamil, H., Patricia, M.J., Teo, A.K. \& Agnes, K. (2017). Socio-environmental Dimensions of Tourist Service Experience in Homestays. International Journal of GEOMATE, 12(34), 96-100

Voss, R.,\& Gruber, T. (2006). The desired teaching qualities of lecturers in higher education: a means end analysis. Quality Assurance in Education, 14(3), 217-242. 